\title{
La circulación de saberes y el problema de la autoría en la prensa virreinal Un análisis del Correo de Comercio, 1810-1811
}

\author{
( Matías Maggio-Ramírez \\ Universidad Nacional de Tres de Febrero I mmramirez@untref.edu.ar / https://orcid.org/oooo-o0o2-1106-1381
}

\section{Resumen}

Los libros y periódicos españoles, que circularon en Buenos Aires a principios del siglo XIX, fueron utilizados por los editores de la prensa porteña como insumos para la gestión de contenidos. Los textos publicados en España fueron leídos para ser transcriptos o reescritos, sin que se mencionara la fuente de origen en la prensa tardocolonial porteña. La falta de mención autoral en los textos supo llevar al equívoco de creer que pertenecía su autoría a quien se consideraba el editor del periódico. El análisis comparativo, realizado gracias a la digitalización de las fuentes impresas españolas por la Hemeroteca Digital de la Biblioteca Nacional de España, permitió hallar las correspondencias entre las fuentes publicadas en España y el periódico porteño Correo de Comercio (1810-1811). Se hallaron textos en el periódico, que durante más de cien años fueron atribuidos a Manuel Belgrano, que habían sido traducidos en España de autores franceses como Veron Duverger de Forbonnais. El análisis de la autoría en el siglo XVIII y principios del XIX en el ámbito cultural hispánico permitió explicar la apropiación de textos ajenos, porque se buscaba favorecer la circulación de las ideas para el fomento del bien común.

The circulation of knowledge and the problem of authorship in the viceregal press. An analysis of the Correo de Comercio, 1810-1811
Palabras clave

Belgrano, Manuel Correo de Comercio Autoría Periodismo colonial Traducción

\begin{abstract}
The Spanish books and newspapers, which circulated in Buenos Aires at the beginning of the 19th century were used by the editors of the Buenos Aires press as inputs for content management. The texts published in Spain were read to be transcribed or rewritten, without mentioning the source of origin, in the Buenos Aires late-colonial press. The lack of author mention in the texts led to the ambiguity of believing that the authorship belonged to who was considered the editor of the newspaper. The comparative analysis, carried out thanks to the digitalization of Spanish printed sources by the Digital Newspaper Archive of the National Library of Spain, allowed us to find the correspondence between the sources published in
\end{abstract}

\section{Keywords}

Belgrano, Manuel Correo de Comercio Authorship Colonial journalism Translation 
Spain and the Buenos Aires newspaper Correo de Comercio (1810-1811). Texts were found in the newspaper, which for more than a hundred years were attributed to Manuel Belgrano, which had been translated in Spain by French authors such as Veron Duverger de Forbonnais. In the analysis of authorship in the eighteenth and early nineteenth centuries in the Hispanic cultural field, it was possible to explain the appropriation of foreign texts, because they sought to favor the circulation of ideas for the promotion of the common good.

Artículo recibido: 26-10-2019. Aceptado: 21-04-2020

\section{Prensa virreinal y circulación del saber ${ }^{1}$}

1. Esta investigación fue realizada gracias al apoyo del Ministerio de Cultura de la Nación en el marco de

la beca "Acciones, Visiones, Representaciones" de 2017 convocada por la Dirección Nacional de Investigación Cultural de la Subsecretaría de Gestión Patrimonial de la Secretaría de Patrimonio Cultural del Ministerio de Cultura.

2. Agradezco la amabilidad y la generosa erudición de Juan Pablo Canala, de la Sala del Tesoro de la Biblioteca Nacional "Mariano Moreno", por darme a conocer el informe sobre el catálogo de la donación belgraniana
La prensa periódica impresa durante el período virreinal en el Río de la Plata, a diferencia de la revolucionaria e independentista, se centró en la mayoría de sus páginas en bregar por visibilizar las buenas costumbres y criticar aquellas prácticas que eran propias de "tiempos idos". También abordó temas ligados a la economía agraria, al comercio, a la geografía económica y a la educación (Martínez Gramuglia, 2009; Maggio-Ramírez, 2008, 2017; Pastore y Calvo, 2005; Navallo, 2010, 2011). La urbanidad de la ciudad de Buenos Aires, acorde a las buenas maneras reinantes en la metrópolis, se mostraba en la prensa para contrarrestar la errada concepción que se tenía sobre los americanos. Los libros, a pesar del océano y las regulaciones, circularon con furor entre la élite letrada porteña. Los impresos fueron las fuentes de información de las noticias e ideas de las metrópolis europeas en Buenos Aires, pero también oficiaron de insumos para dotar de contenido a los periódicos virreinales. Los editores porteños, así como sus colaboradores, transcribieron los textos leídos, en libros o periódicos, en los impresos públicos que dirigieron. En algunas oportunidades se indicaba la fuente de donde se había abrevado. En otras tantas no se hizo mención alguna. La historiografía posterior le atribuyó la autoría de varios artículos a los editores porteños, cuando ellos sólo reprodujeron artículos leídos de la prensa española. El objetivo aquí propuesto es reconstruir la circulación de la cultura impresa española de finales del siglo XVIII y principios del XIX, en la prensa tardocolonial porteña, con especial énfasis en el periódico Correo de Comercio (1810-1811). Se rastrearán aquellos textos que fueron traducidos e impresos en España pero reproducidos en la prensa porteña virreinal, sin indicación de la fuente de origen. De manera secundaría se realizó un primer acercamiento a la problematización del concepto de autoría. Se analizaron artículos seleccionados del Correo de Comercio, para confirmar si era correcto sostener que pertenecía su autoría a Manuel Belgrano. El criterio que se utilizó para la selección fue identificar los artículos que mencionaban una fuente francesa -por ejemplo los Annales de chimie-, como origen del texto, y buscarla entre los libros donados por Belgrano a la Biblioteca Pública de Buenos Aires (Catálogo de la donación del general Manuel Belgrano, 1936)2. También se buscó si la fuente en idioma extranjero, particularmente francés, se encontraba en las bibliotecas del período tardocolonial y revolucionario (Caillet-Bois, 1929; Torre Revello, 1940, 1956, 1965; Furlong, 1944; Primeras donaciones, 1944; Parada, 1998; Peire, 2008). Al no encontrarse la fuente francesa en los inventarios bibliográficos se buscó el texto en el repositorio de la Hemeroteca Digital de la Biblioteca Nacional de España, que tiene digitalizado gran parte de la prensa ibérica. Las coincidencias del contenido entre el Correo de Comercio y los periódicos españoles permitió realizar: la correcta atribución autoral, reponer la importancia de la circulación de los impresos españoles en Buenos Aires y descartar que la traducción local tuviera un rol preponderante en la prensa tardocolonial. 
La irrupción del periódico en la cultura letrada del Buenos Aires tardocolonial abrió un proceso de divulgación del saber. Frente al libro, como soporte tradicional del conocimiento en la cultura impresa, los papeles públicos porteños tenían algunas ventajas. Entre ellas se destacaba la utilización del castellano, que permitía un mayor espectro de lectores que el latín, la brevedad del contenido (aun cuando los artículos continuaran durante semanas), el bajo costo de la suscripción y la variedad de materias que se trataban a diferencia del libro (salvo que fuera una enciclopedia). El periódico fue el signo de los tiempos ilustrados (Goldgel, 2013: 59). La prensa no era ajena a la lógica secuencial de la información del libro, ya que solían contar con la numeración de páginas corrida entre las distintas entregas. La aparición del índice era la señal ineludible que indicaba el fin del tomo y que era necesario emprender la encuadernación de los periódicos. El formato in cuarto, vigente hasta mediados del siglo XIX, favoreció su encuadernación para su resguardo en bibliotecas particulares, así como para favorecer su venta por tomos.

Los temas que se abordaban en la prensa eran la economía política, la fisiocracia, la historia natural, la crítica de costumbres y la literatura didascálica, entre otros tópicos, y tenían su anclaje en los papeles impresos españoles del dieciocho. Éstos a su vez habían abrevado en los impresos The Tatler (1709-1711) y The Spectator (17111712), dirigidos por Joseph Addison y Richard Steele. Los británicos se propusieron, desde la ficción literaria, sacar la filosofía de los gabinetes para llevarla a los clubes. Los géneros literarios retomaban la vieja tradición de los diálogos, así como sueños y ficcionales cartas de lectores con la finalidad de buscar la complicidad con los suscriptores. Estas estrategias buscaban fomentar la reflexión crítica y racional, así como “[...] estimular el cambio de mentalidad y la renovación de las costumbres, [... con el fin de lograr] la corrección de abusos, vicios o «ridiculeces», y la exposición de ideas que favorezcan una sociedad mejor, más moderna e ilustrada" (Urzainqui, 2009). Es decir, se buscó que la prensa oficiara como “[...] un órgano de educación que cure, higienice, podríamos decir, moral e intelectualmente a los españoles" (Urzainqui, 2009). El ciudadano, en el Buenos Aires finicolonial, era aquel "vecino que podía elegir a los funcionarios y que, a la vez, podía ser elegido: españoles o hijos de españoles con limpieza de sangre, raigambre y prestigio" (Casanello, 2008: 19). Los suscriptores de los periódicos tardocoloniales (burócratas, clérigos y comerciantes), creyeron que la prensa podía actuar con fervor pedagógico para que los criollos artesanos y labradores muden sus costumbres (Maggio-Ramírez, 2011, 2017).

Mientras que el libro era la fuente de validación del saber, el periódico lo era de su difusión, y principalmente si se trataba de romper con el pasado. El Semanario de Agricultura, Industria y Comercio (SAIC), que se publicó en Buenos Aires entre 1802 y 1807, anunció en su "Prospecto" bajo la pluma de su editor, Juan Hipólito Vieytes, que: "Ya es llegado el tiempo en que la voz del sabio [...] se deje oír distintamente en el centro de nuestras modernas poblaciones" $(\text { SAIC, } 1802)^{3}$. La modernidad ilustrada se cifró en que la ciudad americana se mantuviera en contacto, gracias a la prensa, con Europa. Mientras que en la campaña bonaerense el labrador estaba condenado a repetir el pasado, en la ciudad letrada se buscaba quebrar el tiempo circular, de la reiteración de los saberes que se transmitían generacionalmente, a partir de los saberes modernos e ilustrados, gracias a la mediación lectora. Vieytes proponía que las novedades sobre la agricultura, el comercio y la industria le llegaran al campesino por la intermediación de "ciudadanos patriotas" y de "párrocos ilustrados", mediante la lectura en voz alta de su periódico. La campaña era sinónimo de la tradición oral, de la cultura popular que repetía su pasado por lo que se necesitaba de la intervención de la cultura impresa para romper con el antiguo régimen (Maggio-Ramírez, 2011). En 1810, Belgrano en el "Prospecto" del Correo de Comercio aseveró haber "visto a algunos de nuestros labradores haber puesto en práctica [... las] saludables lecciones y consejos [...]", en referencia al Semanario de Agricultura, Industria y Comercio, "cuyo
3. La transcripción textual de las fuentes impresas respetará la ortografía y gramática original. 
Editor se conservará siempre en nuestra memoria". Belgrano, al igual que Vieytes, apostaba a la divulgación del saber cuando escribió en el "Prospecto" que buscaba "[...] extender la ilustracion por este medio hasta las clases mas ínfimas que con ansia corren á buscar los papeles que se dan á luz." (Correo de Comercio, [1970]: s/d)

La élite letrada bonaerense en el virreinato del Río de la Plata tuvo múltiples adscripciones identitarias. Se reivindicó como española, tanto por tradición heredada como por seguir los ritmos de las modas y lujos peninsulares, así como americana pero distinta de los pueblos originarios, castas, artesanos y labriegos. También se identificaba como bonaerense, porque había logrado su mayoría de edad frente a la antigua sede virreinal limeña. Las disputas literarias en la prensa dieron cuenta de la construcción identitaria en el plano simbólico (MaggioRamírez, 2015). Los periódicos virreinales fueron un espacio que regló entre sus páginas cómo habitar la ciudad, para estar a la altura de las potencias europeas. Esta necesidad de acortar espacios entre Buenos Aires y los centros de poder, tanto Madrid como Lima, se encontraron en las fuentes impresas que fueron transcriptas en el Correo de Comercio, el último periódico de matriz dieciochesca del ciclo tardocolonial. La particularidad de este periódico es que en la mayoría de sus artículos no indicaban las fuentes de donde habían abrevado los editores, Manuel Belgrano y Juan Hipólito Vieytes.

\section{Las lecturas sobre el Correo de Comercio}

Belgrano en su autobiografía, que se supone comenzó a escribir en 1814 como parte de sus memorias para ponerse al "cubierto de la maledicencia", recordó su aventura impresa en la edición del Correo de Comercio. Bartolomé Mitre recuperó la experiencia periodística de Belgrano y a partir de ese gesto le otorgó el rol de editor y autor de aquellos textos sin firma que aparecieron en el Correo. La atribución autoral realizada por Mitre no fue puesta en duda hasta mediados de 1970 desde la historia de las ideas económicas en Argentina (Fernández López, 1976) y fue un problema olvidado por la historia del periodismo de principios del siglo XIX.

A finales de 1809 el virrey Baltasar Hidalgo de Cisneros anhelaba la publicación de un periódico en Buenos Aires y "era tanta su ansia, que hasta quiso que se publicase el prospecto de un periódico que había salido a la luz en Sevilla, quitándole sólo el nombre y poniéndole el de Buenos Aires", tal como escribió Belgrano (1960: 966) en su Autobiografía. Tal vez el periódico al que se hacía referencia fue el Correo de Sevilla, cuyo prospecto se conoció con fecha del 1 de octubre de 1803. Gracias al afán del virrey para que Buenos Aires contara con una publicación periódica, pudo reunirse Belgrano en la confabulación revolucionaria. Cisneros creía que los encuentros tenían como motivo tratar la edición del impreso.

En el Correo de Comercio no se encontró referencia alguna a Manuel Belgrano, por ejemplo en la firma de artículos, aunque él mismo recordó haber redactado el prospecto del "Diario de Comercio" [Correo de Comercio]. El periódico contó con la autorización virreinal impresa con fecha del 24 de enero de 1810 y se publicó entre el 3 de marzo de ese año y el 6 de abril de 1811. Entre los considerandos para solicitar la autorización virreinal se destacó que desde la segunda invasión inglesa dejó de aparecer el Semanario de Agricultura, Industria y Comercio (1802-1807), por lo que era una vergüenza que la gran capital de la América Meridional no tuviese un periódico. Belgrano aseveró que en el Correo de Comercio "salieron mis papeles" que oficiaron como "una acusación contra el gobierno español; pero todo pasaba, y así 
creíamos ir abriendo los ojos a nuestros paisanos: tanto fue, que salió uno de mis papeles, titulado: Origen de la grandeza y decadencia de los imperios" (Belgrano, 1960: 966). En realidad hacía referencia al artículo "Causas de la destrucción o de la conservación y engrandecimiento de las Naciones", que se publicó el sábado 19 de mayo de 1810. Se realiza tal atribución porque el título indicado en sus memorias no se corresponde con ningún texto publicado en el Correo de Comercio, es uno de los pocos textos que utilizan la palabra "imperio" y que no es una transcripción de la prensa española, y por último es la única pieza que se conoció en el impreso que aborda la temática del título (Correo de Comercio, 1970: 89).

Entre los primeros estudios que le atribuyeron la autoría del Correo de Comercio a Manuel Belgrano fue Bartolomé Mitre (1859: 205-207) al rescatar los datos de la autobiografía citada. Mitre destacó en Belgrano la dirección del periódico, su ideario y citó el prospecto del impreso, junto con los fragmentos de la autobiografía que hacían referencia a su aventura literaria. Si bien Mitre mencionó en varias oportunidades la amistad y sintonía política entre Juan Hipólito Vieytes y Belgrano, no le atribuyó la autoría de ningún artículo al arequero ni tampoco en el criterio curatorial en la selección de artículos. Juan María Gutiérrez (1866: 231-233) estableció la duración del periódico entre el 3 de marzo de 1810 y el 23 de febrero de 1811, tanto los pliegos principales como los suplementos por lo que se intuye que no tuvo a la vista una colección completa. Luego de glosar el prospecto, enunciar los títulos de los principales artículos y destacar que nada indicaba en la prensa las huellas del proceso revolucionario, citó la autobiografía de Belgrano para recordarlo como uno de "los más luminosos y simpáticos en la lista de argentinos célebres". El relevamiento de Gutiérrez fue la norma entre los investigadores que le siguieron a la hora de abordar el periódico. Antonio Zinny (1869: 28) fue el primero en asegurar que Juan Hipólito Vieytes fue colaborador del Correo de Comercio, pero no marcó los indicios que sostenían sus sospechas. A partir de allí distintos escritos, sin dudarlo, mencionaron al erudito arequero como director, redactor o colaborador del periódico (Torre Revello, 1940: 199; Beltrán, 1943: 32; Galván Moreno, 1944: 40; Rivera y Quintana, 1945: 91; Weinberg, 1956: 30; Caillet-Bois, 1958: 238; Catálogo del periodismo, 1960: 20; Furlong, 1969: 77; Fitte, 1970: 12; Martini, 1999: 329; Fernández López, 2005: 6). A más de doscientos años del primer número del Correo de Comercio se sostuvo sin duda alguna, desde la historia de la comunicación, que "[...], el periódico casi en su totalidad fue escrito por su director [Manuel Belgrano] Luego de su partida [al Paraguay] la dirección recayó en su discípulo y amigo Juan H. Vieytes [...]" (Díaz, 2012: 275-276). Entre las últimas publicaciones del Instituto Nacional Belgraniano se encuentra la antología realizada por Matías Dib (2016:31) en donde con prudencia puso de relevancia que Vieytes tuvo un destino revolucionario en Córdoba y que para octubre de 1810 ya se encontraba en Buenos Aires por lo que "[h]ubo de presumirse que Vieytes asumió el cambio de dirección del Correo de Comercio". Los principales estudios introductorios a las antologías y reproducciones facsimilares del periódico (Weinberg, 1954; Fitte, 1970; Gómez de Mier, 2003; Gagliano, 2011; Dib, 2016) tomaron como cierto la autoría de Manuel Belgrano de la mayoría de los artículos y dejaron a Juan Hipólito Vieytes rol de editor sustituto a partir de septiembre.

Las lecturas sobre el Correo de Comercio fueron reiterativas. Hicieron hincapié en el recorte temático, en el fomento de la Academia de Música, en los versos de Prego de Oliver, bajo sus iniciales (J.P.D.O.) así como de Vicente López (V.L.) y se reprodujeron fragmentos de la autobiografía (Rojas, 1924: 768-769) ${ }^{4}$. En la década del setenta del siglo XX, el economista Manuel Fernández López (2005:1) encontró que pasajes del artículo "Economía política" que se publicó en el Correo de Comercio era una transcripción, sin citar la fuente de partida, de las cartas de
4. La historia de la prensa glosó con ahínco a Zinny como en las plumas de Juan Pablo Echagüe (1938: 91-92), José Torre Revello (1940: 199-200), Gutiérrez (1866), Oscar Beltrán (1943: 30-37), Juan Rómulo Fernández (1943: 45-46) y Carlos Galván Moreno (1944: 49) que volvieron sobre la bibliografía secundaria para describir los principales temas tratados, se transcribió el prospecto y las estrofas de los versos de Vicente López dedicada al labrador; para indicar que a diferencia del Semanario se incluyeron versos con gran mesura en el Correo de Comercio. En la revista El Monitor de la Educación Común, dependiente del Ministerio de Justicia e Instrucción Pública, se publicó un número doble bajo el título: "Los géneros periodísticos en la época colonial”. Ángel Rivera y Raúl Quintana (1945: 91-96) además de sostener que "como se sabe" Belgrano y Vieytes fueron los principales redactores suponen que fue éste quien "quedó al frente del periódico cuando el vocal de la Junta, en agosto de 1810 , debió ponerse al frente de la expedición libertadora al Paraguay" (p. 91). Guillermo Furlong (1969: 77-78) no sólo glosó a Rivera y Quintana sino que es uno de los pocos autores que duda sobre la autoría de los textos del periódico: "Es posible que, como escribió Belgrano en su Autobiografía, volcó él en esta publicación algunos de los artículos que había escrito en pro de la independencia del país, pero no es fácil señalar cuáles son [...]" (p. 77). 
5. Fernández López sostuvo que la censura virreinal fue una de las razones por las que el autor de un documento cedía la "paternidad de su obra", aunque en rigor serían las ideas o postulados, para que fuera reescrito por otro con mayor peso simbólico en el campo literario académico del pequeño universo letrado porteño. La historiografía incurrió, según Fernández López (1976: 4), en un "enfoque tendencioso de considerar los escritos de un autor con aislamiento de los demás" miembros de la comunidad letrada. Para el investigador, los textos manuscritos que se conocieron con el título "Nuevo aspecto del comercio en el Río de la Plata", atribuido desde 1955 por Enrique Wedovoy (1955: 1-108) a Manuel José de Lavardén, deberían tener como autor a Pedro Cerviño ya que parten de una memoria que leyó en el Consulado de Comercio en noviembre de 1799 (Fernández López, 1976). Años después Fernández López (2005) rastreó la influencia y apropiación de las cartas de Valentín de Foronda en el Semanario de Agricultura, Industria y Comercio a partir de una reescritura de Vieytes que firmó como Julián Topio, anagrama de Juan Ipólito. El texto "Carta dirigida al Editor desde la cárcel de esta ciudad", publicado en el Semanario (7/12/1803: 108-11) retomó la Carta I de Foronda. En otra carta dirigida al editor, que se publicó en 1804 bajo el título: "Sobre la necesidad de favorecer la exportación de frutos" se transcribieron doce páginas de Foronda publicado en 1794 (Fernández López, 2005: 5). Al firmar como "Su apasionado H." se descubrió a "Vieytes en la inicial de su segundo nombre [... como] gesto de admiración a Foronda, al imitar la expresión que el vitoriano solía firmar sus epístolas" (Fernández López, 2005: 6). El SAIC solía dar mención a la fuente donde abrevaba, como por ejemplo con

El espíritu de los mejores diarios o el Semanario de Agricultura y Artes dirijido a los párrocos pero no fue así con los textos de Foronda. En las investigaciones de Félix Weinberg (1956), Torre Revello (1956), Maggio-Ramírez (2008) y Martínez Gramuglia (2009) pueden hallarse las fuentes impresas consultadas por Vieytes en su periódico. Aunque en la investigación en curso se espera demostrar que la mayoría de las fuentes en las que abrevó Vieytes fueron los impresos españoles, que tradujeron a la prensa francesa.
Valentín de Foronda. ${ }^{5}$ Fernández López (1976: 14) argumentó que la mera transcripción operaba como una identificación por parte de los editores con los postulados de Foronda. Las ideas del ilustrado español estuvieron presentes en las memorias del Consultado, bajo la gestión de Belgrano, en el Semanario de Agricultura de Vieytes, y en el Correo de Comerció.

\section{El problema de la autoría a fines del siglo XVIII y principios del XIX}

La producción periódica se sustentaba por la suscripción previa al lanzamiento del impreso. Este modelo era propio de la tradición inglesa que contaba con un potente público lector (Martínez de Sousa, 2004: 615; Finkelstein y McCleery, 2014:142). Los Borbones, a pesar del tradicional Consejo de Castilla, tenían la certeza de que la prensa era un signo de modernidad. Felipe V sostuvo el Diario de los Literatos, Fernando VI, su sucesor, hizo lo propio con el Diario noticioso; hasta que durante el reinado de Carlos III aparecieron El Pensador, El Censor, el Espíritu de los mejores diarios y el Correo de Madrid. El aumento de las publicaciones necesitó de la certeza de compra por parte de los lectores, por lo que se utilizó el sistema de suscripción. Este modelo conllevaba que, una vez obtenidas las licencias, el editor debía imprimir un "Análisis" o "Prospecto" donde indicaba a los potenciales suscriptores los temas que tratarían. Los papeles impresos decidían incorporar al comienzo de cada tomo una lista de suscriptores como "una importante e indispensable fuente publicitaria", pero para los abonados significaba también "un modo de distinción social y cultural”, porque allí se encontraban el monarca, el clero, los nobles, la administración e intelectuales de renombre (Larriba, 2013: 37). La suscripción implicaba compartir una comunidad de lectores privilegiados, porque podían pagar por adelantado el periódico a diferencia de los compradores de números sueltos o lectores "de gorra" en los cafés. La inclusión en la lista implicaba una manera de reunirse con la élite para leer y discutir los temas que se proponían en el impreso. El suscriptor sabía que aportaba "un sustento económico al autor, pero lo esencial es hacerlo saber. Y los editores lo comprendieron perfectamente" (Larriba, 2013:38). Los periódicos dieciochescos fueron descriptos por contar con "un pequeño formato, letra apretada, papel de baja calidad, escasísimas ilustraciones, su vocación de continuidad mediante la dosificación periódica, [y] el tipo de contenidos [...]" (Urzainqui, 2003: 378). Estos fueron aceptados, fomentados y cuestionados por sus lectores, quienes también sostuvieron la empresa periodística al ser suscriptores.

En aquellos países con un "mundo cultural más desarrollado que España" (Deacon, 2014: 108), cuando ya no era necesario para el creador "complacer a un mecenas o cliente", fue primordial incluir en la portada el nombre del autor, como garantía de calidad, para que pudieran promocionarse los libros (Deacon, 2014; Finkelstein y McCleery, 2014). El libro impreso a partir del siglo XIV “afirmó la práctica de no reunir en un mismo libro más que textos" de un mismo autor (Chartier, 2016: 24). Ese gesto cuestionó la tradición de la cultura escrita porque durante "la edad del manuscrito, la de las misceláneas que [reunían] textos de géneros, fechas y autores muy diferentes" (Chartier, 2016: 25). Mientras que el libro se consolidaba como la unidad material ligada al discurso de un autor, en la prensa las voces se multiplicaban. Los periódicos, que solían tener la numeración correlativa en sus páginas, se encuadernaban en un tomo. La prensa se alejó del libro, al fragmentar la información para hacerla más accesible pero volvían al formato, encerrado entre dos tapas, para buscar nuevos lectores. Los periódicos encuadernados en tomos cruzaron con facilidad el Atlántico. Principalmente porque su contenido no se centraba en la narración de eventos, y sí en la crítica de costumbres, saberes ilustrados o reseñas literarias como en el Semanario de Agricultura y Artes o el Espíritu de los mejores diarios. El tiempo del acontecimiento no marcaba la urgencia de la lectura. Las costumbres y saberes ilustrados no caducaban 
de un año al otro. De hecho, Vieytes en su Semanario escribió que accedió a la "colección" del Semanario madrileño, como una estrategia para dar cuenta que tenía acceso a la totalidad de un saber y que pensaba transcribirlo para sus lectores americanos. La prensa española del XVIII cuando anunció la aparición de nuevos libros y sus puntos de venta terminó por ampliar el espacio en sus páginas para incluir reseñas. La figura del autor se destacaba en la prensa, aunque sea en las polémicas literarias.

En Buenos Aires, el primer periódico impreso se sostuvo gracias a la suscripción del público y del Consulado de Comercio. Cabello y Mesa supo incluir la lista de suscriptores, principalmente burócratas virreinales, eclesiásticos y comerciantes (Martini, 1998; Martínez Gramuglia, 2010), y se supone que ese grueso de lectores se mantuvo en el Semanario de Vieytes y en el Correo de Comercio, ya que ninguno de ellos incluyó la nómina de sus suscriptores. Para obtener las suscripciones Vieytes prometió en su "Prospecto" tener a la "vista los mejores Autores así nacionales como Extrangeros" de estos "últimos tiempos" y consultar "los mejores periodicos de Europa". Belgrano apuntaba a seguir los pasos de Vieytes, con un perfil pedagógico: instruir al comerciante.

Las lecturas que realizaban los editores porteños de la prensa española, pronto terminaban por copiarlas en sus impresos. Por ejemplo, la curaduría de lecturas realizadas por Cristóbal Cladera y glosadas en El espiritu de los mejores diarios que se publican en Europa, fueron transcriptas en Buenos Aires, aunque en varias oportunidades sin mencionar la fuente. Esta fue una de las estrategias que utilizó tanto el Semanario de Vieytes como el Correo de Comercio, por ejemplo para dar a conocer las ideas de Valentín de Foronda. El primer periódico porteño, editado por Francisco Cabello y Mesa, transcribió en más de una oportunidad y sin dar crédito, textos tomados del Correo Mercantil madrileño (Martini, 1998: 217). Tanto Cabello y Mesa como Vieytes solían invitar a los lectores y suscriptores, que añoraban ver su nombre en letras de molde, para que aportaran sus reflexiones sobre los temas de los periódicos. Completar las páginas del impreso cada semana no era tarea fácil. Las cartas al editor, por momento ficcionales, así como informes de viajes, poemas didácticos o reflexiones sobre los temas que abordaban los impresos, eran las colaboraciones que recibían los editores de los suscriptores americanos.

Entre las prácticas de la cultura escrita, propia del humanismo, estaba llevar un cuaderno de anotaciones con fragmentos de las lecturas realizadas. Los "frutos de las lecturas" se guardaban como las flores entre los libros. Se transcribía lo leído de diferentes fuentes impresas para guardarlo en la memoria del papel. Luego se organizaban los fragmentos a partir de palabras claves. Éstas se ordenaban alfabéticamente para copiarlas en otro cuaderno, junto con los fragmentos de los textos que se había leído y catalogado. Los letrados tardocoloniales mantuvieron esta práctica, aunque solo pocos documentos llegaron hasta hoy día. Entre ellos se destacan los cuadernos manuscritos de Saturnino Segurola, quién fuera segundo bibliotecario de la Biblioteca Pública de Buenos Aires, bajo el título Apuntes varios sobre física, química, historia natural y demás ramos profanos pertenecientes al estudio del D. D. Saturnino Segurola. Se puede llamar con propiedad esta obra Fruto de mis lecturas?. La escritura posterior a la lectura, aunque era una práctica propia del ámbito privado, se hizo público en la prensa. Los editores, lectores al fin de los periódicos españoles que habían comprado con anterioridad a su aventura impresa, daban a conocer sus lecturas al público. Las transcribieron y las catalogaron, por ejemplo al cambiarles el título respecto a la fuente original. La tradición humanística pervivió hasta finales del siglo XIX, por ejemplo Bartolomé Mitre supo llevar un diario de juventud donde daba cuenta de las lecturas que fueron el puntapié para la escritura de la novela Soledad. Mitre escribió allí, "Leamos, apuntemos y después meditaremos" que replicaba el rol del editor de la prensa colonial que leía para transcribir aquello que imaginaba útil a la comunidad y que tendrían a los suscriptores como mediadores de la palabra impresa ante los labradores (Parada, 2012).
6. Fernández López halló que la primera carta que aborda el tema de los gremios, "publicada en los números 14 y 15 ( 2 y 9 de junio) [...] sigue fielmente la carta VI de Foronda [...] Algunas frases son calcadas de Foronda, como: "El derecho de trabajar es una obligación impuesta al hombre por el autor de la naturaleza, es tan sagrada ..." (p. 109 del Correo; Foronda 1789: 59)." (Fernández López, 2005: 7). El artículo "Economía política", que se publicó en los números 26 y 27 del Correo siguió el plan de la carta IV de Foronda, publicada en El espíritu de los mejores diarios literarios del 1 de diciembre de 1788. Al año siguiente se recopilaron en el volumen Cartas sobre los asuntos mas exquisitos de la Economía-Política, y sobre las leyes criminales. Escritas por Don Valentín de Foronda, de la Real Academia de Ciencias y bellas Artes de Burdeos y se imprimió en la casa de Manuel González. Si bien no se puede distinguir cuál fue la fuente principal se supone que los textos de Foronda se leyeron y transcribieron frases exactas en el Correo de Comercio a partir del periódico de Cristóbal Cladera que tuvo una amplia circulación en el Río de la Plata y fuera fuente de transcripciones por parte de Vieytes (Torre Revello, 1965; Peire, 2008). Si bien el texto estaba firmado por Almada, para Fernández López podría ser Vieytes quien reescribió la carta de Foronda. La hipótesis sería atendible ya que con anterioridad ya se había apropiado de sus ideas, que circularon en uno de los periódicos en los que abrevó para transcribir textos para el SAIC. Cabe destacar que Fernández López realizó la comparación a partir de la recopilación de las cartas en el libro y no con el periódico como hoy lo permite la Hemeroteca Digital de la Biblioteca Nacional de España.

7. El manuscrito se puede consultar en el Archivo General de la Nación de la República Argentina. Agradezco a Jaime Peire por indicarme la fuente y permitirme el relevamiento fotográfico de la misma. Segurola, Saturnino. sine data. "Apuntes varios sobre física, química, historia natural y demás ramos profanos pertenecientes al estudio del D. D. Saturnino Segurola. Se puede llamar con propiedad esta obra Fruto de mis lecturas". AGN, BN, 53. Buenos Aires. 
8. Vale recordar que tampoco han de leerse la totalidad de las epístolas publicadas como una respuesta del público. La correspondencia que se incluyó en la prensa fue en algunos casos un artilugio retórico para acercar y buscar la identificación del lector con el corresponsal ficcional. El género epistolar fue utilizado en la prensa española del siglo XVIII para proponerle al lector una reflexión educativa, con un fin didáctico instruccional, como un giro en primera persona a la crítica de costumbres que usualmente era escrito por un personaje ficticio (Aullón de Haro, 1987).
Se realizó en la prensa virreinal la copia del texto ajeno y en ocasiones los editores cambiaban algunas palabras por sus sinónimos. El texto de origen, que había sido traducido en España, se modificaba en su transcripción local. Tal vez para evitar su rápida identificación por parte de los letrados porteños, que también contaban con esos tomos de los periódicos en sus bibliotecas. Tanto Cabello y Mesa, Vieytes, y la dupla de Belgrano y Vieytes transcribieron en sus periódicos textos provenientes de libros y papeles públicos. Los directores de los periódicos porteños tuvieron acceso a impresos en castellano, francés e inglés pero privilegiaron las traducciones realizadas en España a la hora de copiar los textos en sus impresos. La periodicidad semanal de los periódicos, conspiraba contra el tiempo de la traducción y su revisión. En Buenos Aires se leía con escasa demora lo mismo que en Europa. La utilización de las versiones españolas de fuentes francesas fue una constante en los periódicos tardocoloniales porteños.

El análisis textual del Correo de Comercio y su comparación con la prensa europea, que también fuera utilizada como fuente en los periódicos precedentes, sirvió para comenzar a diluir el pesado sello que lacró las interpretaciones sobre la autoría de los artículos. Las discusiones sobre la autoría en el ámbito borbónico francés, analizadas por Roger Chartier (2006b: 215-238), sirvieron para dar al menos una explicación a las distintas estrategias por parte de los editores para el uso de textos ajenos en favor del bien público. De hecho Condorcet creía que la propiedad literaria era un "privilegio" que era nocivo para "el "interés público" porque es "una traba impuesta a la libertad, una restricción a los derechos de los otros ciudadanos"» (Chartier, 2006b: 233). En el siglo de las Luces se buscó para potenciar el progreso y el bien común que «cada uno pueda libremente componer, mejorar, reproducir, difundir las verdades útiles a todos; de ninguna manera pueden ser objetos de una apropiación individual» (Chartier, 2006b: 233). Mientras que Denis Diderot, quien apelaba a "la propiedad de los autores sobre sus obras [como] un derecho legítimo e inalienable" (Chartier, 2006a: 30), vivía de su pluma, el Marqués de Condorcet lo hacía gracias a las rentas (Chartier, 2006a: 30-31).

Tal vez el ideario fomentado por Condorcet operó en las prácticas periodísticas de los editores en Buenos Aires cuando transcribieron fragmentos de textos que les eran ajenos, porque lo importante era el mensaje y no la personalidad o la vida del autor. Los periódicos virreinales contaban con censura previa, por lo tanto no sería pertinente pensar aquí de forma análoga el anonimato con la crítica disruptiva al orden establecido de la sátira, que habían sido prohibidos por Carlos III (Deacon, 2014: 109). Eso no significaba que no circularan en copias manuscritas como la "Sátira" de Manuel José de Lavardén contra Juan Manuel Fernández de Agüero y Echave (Maggio-Ramírez, 2015). Belgrano utilizó la primera persona del plural para indicar que la tarea editorial sería compartida. A diferencia de los periódicos anteriores donde tanto Francisco Cabello y Mesa como Juan Hipólito Vieytes utilizaron la primera persona del singular para referirse a su tarea editorial. Tal vez se optó por el trabajo compartido de la edición del periódico porque, de acuerdo a las experiencias anteriores, los lectores no respondían a las convocatorias escriturarias y los suscriptores se escondían cuando los visitaba el cobrador. En el marco de la historia del periodismo rioplatense se identificó tradicionalmente el rol del editor del Correo de Comercio a Manuel Belgrano. Aquí se utilizará el plural, porque tanto el virrey Cisneros como los lectores contemporáneos al periódico se referían a los editores. Se podría suponer entonces que entre la pequeña comunidad letrada de suscriptores se sabía que el periódico contaba con más de un editor ${ }^{8}$. La utilización de las mismas fuentes españolas, el criterio temático y el resguardo que se tuvo en no duplicar textos que ya habían sido publicados en el Semanario de Agricultura, Industria y Comercio, permitirían suponer que tanto Belgrano como Vieytes oficiaron de editores del Correo de Comercio en distintas etapas. 
Cabello y Mesa, en su "Análisis", advirtió a sus lectores que: "muchas veces vomitaré párrafos enteros de mis libros tan íntegros, y perfectos como la ballena a Jonás en los campos de Nínive; pues no deja de ofrecerme que para empresa tan basta, necesito de un estómago de tanto buque como el de aquel vizcaíno del que habla el diario pinciano de Valladolid, so pena de exponerme a mortal apoplegía [sic]". Vieytes en el Semanario deAgricultura les avisó a sus lectores que tendría a la vista los mejores autores nacionales como extranjeros que hayan tratado los temas del título y que consultaría los periódicos europeos a los que se había ya suscripto con antelación. En rigor fue un eufemismo en el que ambos anunciaban la transcripción de algunos artículos de la prensa española para que el lector pudiera acceder desde Buenos Aires a las discusiones metropolitanas. No siempre se incluyó la mención de la fuente donde eran tomados los textos que se publicaban y pasaron por creerse propios de la pluma del editor o firmante del prospecto del periódico.

La prensa tardocolonial porteña fue un espacio donde se condensó la circulación de fuentes impresas de distintos orígenes. Al igual que un florilegio de lecturas se seleccionaban los textos europeos de acuerdo a los intereses locales. El caso del Telégrafo Mercantil es emblemático para pensar este problema. Cabello y Mesa comparó a la lectura como el alimento y al ser tanto lo que había leído para producir su periódico prometía vomitar sus lecturas en las páginas del Telégrafo. Eso sí, mantenía el compromiso de no alterar los párrafos leídos para copiarlos en su impreso. Los periódicos dieciochescos y de principios del siglo XIX retomaban la tradición de los cuadernos de lugares comunes o frutos de lecturas, que tenían tanto fines didácticos como de ayuda memoria, ya que recopilaba el espíritu de una obra, aquello que era necesario recordar. Las lecturas de los editores eran copiadas en sus periódicos con el afán de generar, como escribió Cabello y Mesa en el "Análisis" del Telégrafo, "una especie extraña de contagio, [para transmitir] las meditaciones de los hombres, comunicando el calor patriótico de persona en persona, de provincia en provincia $[. .]$.$" ".$

La transmisión del saber centrado en la cultura impresa tuvo en Buenos Aires como principal motor el fomento de la felicidad pública. La prensa fue el vehículo para que el saber de la sabia Europa, al decir de Vieytes, llegara a los ciudadanos y párrocos para luego difundirlo entre los labradores de la campaña y la feligresía. El principal eje se centró en la modificación de las costumbres para desterrar los hábitos propios de tiempos idos, como los métodos de labranza, para poder abrazar la modernidad del saber ilustrado (Barral, 2007; Maggio-Ramírez, 2008; Martínez Gramuglia, 2009). Para acceder al conocimiento validado desde las metrópolis, la prensa fue el principal instrumento que utilizó distintas estrategias para hacerse de ese saber. Alejados de los centros metropolitanos de producción de libros y periódicos, territorios donde regían las licencias de impresión que otorgaba el derecho sobre un título al librero/impresor, en Buenos Aires los editores solicitaban colaboraciones, ficcionalizaban cartas de lectores o simplemente transcribían sus lecturas. Para Condorcet la propiedad literaria atentaba contra el progreso de las luces porque "instituye el monopolio de uno solo sobre un saber que debe ser un bien común" (Chartier, 1994: 67) ya que las ideas pertenecían a todos, no así las formas de escribirlas. De alguna manera la práctica de los editores de periódicos porteños se encontró en sintonía con la propuesta de Condorcet al "apropiarse" sin pudor de traducciones realizadas en libros y periódicos. Las ideas de esos textos se consideraban necesarias para los lectores, por lo que eran transcriptos con algunas mínimas modificaciones, como la inclusión de una nota al pie o la utilización de sinónimos.

La necesidad de acortar las distancias entre el centro y la periferia de la cultura impresa justificó, quizá, la transcripción de textos europeos en la prensa porteña. La principal fuente española, donde abrevaron el Semanario de Agricultura, Industria $y$ Comercio como el Correo de Comercio, fue el Semanario de Agricultura y Artes dirigidos a los Párrocos. 


\section{De la biblioteca al Correo de Comercio}

\begin{abstract}
Es muy notable y sensible, que perdiendo tantos su tiempo en hacer traducciones de romances, novelas y otras obras propias solo para corromper el gusto y las costumbres, no lo empleen en aquellas que tienen un mérito distinguido y son de utilidad general. Hasta el año de 1794 no hemos tenido una traducción de la obra maestra de Adam Smith, Riqueza de las Naciones. José Ignacio de Pombo (Silva, 2005: 16)
\end{abstract}

Los temas que abordó el Correo de Comercio estaban enunciados en el prospecto. Se apelaba a un espectro que abarcó "[...] todo el ramo de las Ciencias y las Artes conocidas" para instruir al comerciante, al labrador y al "industrioso" porque uno sin otro es imposible que "logren más que unos adelantamientos efímeros, y que de suyo se derrocan", según Belgrano (Correo de Comercio, 1970). Los tres actores principales eran las encarnaciones del título del Semanario de Vieytes pero en distinto orden. A pesar que Belgrano recalcara la falta de libros en los confines del imperio borbónico, se encontraron en el Correo de Comercio la transcripción fragmentaria de algunos títulos. Si los libros eran la fuente del saber, el periódico lo era de su difusión.

Además de las cartas de Foronda, descubiertas por Manuel Fernández López, también se halló la lectura de Adam Smith por parte de la élite criolla (Chiaramonte, 2007: 73; Pastore y Calvo, 2000; Fernández Armesto, 2005; entre otros autores). Tanto José Torre Revello (1956) como Verónica Fernández Armesto (2005) encontraron entre los lectores de Smith a Juan Hipólito Vieytes. En el inventario de su biblioteca realizado por el bibliotecario José Luis Chorroarín en 1815 se anotó la edición española de 1794 que había sido expurgada respecto de la publicación original inglesa de 1776. Un fragmento de la Riqueza de las naciones fue en parte glosada en el artículo "Comercio", publicado en el primer número del Correo de Comercio el 3 de marzo de 1810: "Un país que no tiene minas, dice Smith, debe por necesidad arrancar la plata y oro de los países extranjeros, del mismo modo que el que no tiene viñas conduce el vino que necesita consumir", (Correo de Comercio, 1970: 5). Pero también se utilizaron frases textuales tomadas de la misma edición española que tenía Vieytes en su biblioteca.

\begin{tabular}{|c|c|}
\hline $\begin{array}{l}\text { Correo de Comercio, número 1, } 10 \text { de marzo de } \\
\text { 1810: } 9\end{array}$ & $\begin{array}{l}\text { Smith, Adam. 1794. Investigación de la } \\
\text { naturaleza ..., Volumen 2: } 259\end{array}$ \\
\hline $\begin{array}{l}\text { "Quando la cantidad de plata y oro que } \\
\text { se introduce en algún país, mediante el } \\
\text { comercio, exceda en algo a la demanda } \\
\text { efectiva, es inevitable su exportación; } \\
\text { porque el interés del hombre siempre activo } \\
\text { calculando en su favor, corta fácilmente } \\
\text { toda traba y obstáculo". }\end{array}$ & $\begin{array}{l}\text { "Quando la cantidad de oro y plata que se } \\
\text { introduce en un país excede de la exigencia } \\
\text { efectiva de él, no hay vigilancia ni gobierno } \\
\text { capaces de impedir absolutamente su } \\
\text { extracción" }\end{array}$ \\
\hline
\end{tabular}

9. Se puede encontrar en la Biblioteca Nacional de Maestro un micrositio web donde puede descargarse el portafolio educativo con los textos del Correo de Comercio cuya autoría se atribuye a Belgrano http://www.bnm.me.gov.ar/erecursos/recursos_didacticos/portafolios/belgrano_politica/economico.htm (Consultado, 25/10/2019)

El artículo con el título "Comercio", atribuido a Manuel Belgrano en la totalidad de estudios dedicados al análisis del Correo de Comercio (Weinberg, 1954; Gagliano, 2011; Arata, 2011; Dib, 2016; Pigna, 2016), se publicó por entregas entre el número 27 del tomo I hasta el número 6 del tomo II para quedar incompleto por la falta de continuidad del periódico'. Es decir, se publicó entre el 1 de septiembre de 1810 y el 6 de abril de 1811, y sus diversos apartados fueron atribuidos a Belgrano. El extenso artículo es una versión casi completa de la traducción de los Elémens du commerce de Véron Duverger de Forbonnais. La edición en castellano se publicó en Madrid en 1795 con la traducción que Carlos Lemaur, ingeniero y arquitecto francés. El libro de 
Forbonnais recopilaba las entradas en orden alfabético de temas económicos que formaron parte de la Enciclopedia de Diderot y D' Alambert. El ingeniero Carlos Lemaur procuró traducir la obra desde «una visión más amplia de formación para todos "aquellos que quieran entrar en el manejo de los negocios públicos" y los cuales no "pueden sin riesgo descuidarse en el estudio del comercio y de la hacienda" (Astigarraga y Zabalza, 2009).

En la Europa dieciochesca, así como en los confines coloniales, escribir sobre economía era hacerlo sobre política y gobierno. Más aún en el ámbito hispánico donde bajo la égida virreinal no había un debate político abiertamente. Durante el reinado de Carlos III y hasta 1812 se publicaron casi un centenar de obras sobre economía política de distintas doctrinas y géneros discursivos desde periódicos, diccionarios o enciclopedias (Usoz, 2013: 83-84). Los editores del Correo de Comercio encontraron en la economía política una propuesta sobre política y gobierno en tiempos revolucionarios. Transcribieron la traducción española con algunas modificaciones, se apropiaron de las ideas como aconsejaba Condorcet. Los dos tomos de los Elementos del Comercio de Forbonnais, traducidos por Carlos Lemaur, fueron publicados sin mención de autoría ni de traducción en el Correo de Comercio. Si bien la edición en francés tenía un capítulo sobre "Las colonias", al no contar con el segundo tomo de la traducción castellana no se puedo aventurar si fue decisión de Carlos Lemaur eliminar ese capítulo o si los editores porteños decidieron no publicarlo. Se transcriben aquí algunos párrafos para comparar entre el tomo 1 de Elementos de Comercio bajo la traducción de Carlos Lemaur y su transcripción en el Correo de Comercio.

Correo de Comercio, 1 de septiembre de 1810, número 27: 204.
Elementos del Comercio. Véron Duverger de Forbonnais. Traducción y versión al castellano de Carlos Lemaur, 1795.

Capítulo 1. Del comercio en general.

Por la palabra comercio entendemos el cambio, que los hombres hacen entre sí de las producciones de sus tierras, y de su industria. Ha querido la providencia mediante la variedad de la naturaleza, que es obra suya, poner los hombres en una mutua dependencia; y el Altísimo ha formado el enlace, que les une a todos, mostrándoles su amor y omnipotencia por el conocimiento que les ha dado de las maravillas de que llenó el universo.
Comercio, en su sentido general, debe Él se aplica más particularmente a la comunicación que los hombres hacen entre sí de las producciones de sus tierras y de su industria. La providencia infinita, cuya obra es la naturaleza, ha querido por la variedad de que la ha adornado, poner a los hombres en dependencia unos de otros. El Ser Supremo ha formado en ella los lazos, a fin de conducir a los pueblos a conservarse entre sí, para reunir el tributo de sus alabanzas, manifestándoles su amor y su grandeza por el conocimiento de las maravillas de que ha llenado el universo. número 28: 209
Principios fundamentales del comercio, sacados de la experiencia. p. 42. 1a) Se han visto pueblos suplir por la industria el defecto de las producciones de la tierra y poseer más riquezas de convenciones, que aquellos que eran propietarios de las riquezas naturales; pero esta industria consistía siempre en distribuir a cada país las riquezas naturales de que estaba necesitado; y recíprocamente, sin industria ningún pueblo ha poseído abundantemente el oro y la plata, que son las riquezas de convención.
1. Se han visto algunas Naciones suplir por su industria el defecto de las producciones de la tierra, y poseer mas riquezas de convención, que los mismos propietarios de las riqueza naturales. Pero consistía siempre esta industria en la distribución de las ultimas riquezas en los países que no las tenían; y recíprocamente sin industria ninguna Nación puede poseer con abundancia el oro, y la plata, que son las riquezas de convención. 


\begin{tabular}{|c|c|}
\hline número 28: 212 & Principios especulativos del comercio: 48 \\
\hline $\begin{array}{l}\text { Antes de examinar cómo los legisladores } \\
\text { vienen a llenar el objeto, y el efecto del } \\
\text { comercio, yo expondré nueve principios que } \\
\text { los ingleses, es decir, el pueblo más sabio } \\
\text { en el comercio, proponen en sus libros para } \\
\text { juzgar de la utilidad o de la desventaja de las } \\
\text { operaciones de comercio. } \\
\left.1^{\circ}\right) \text { La exportación de lo superfluo es la } \\
\text { ganancia más clara que puede hacer una } \\
\text { nación. }\end{array}$ & $\begin{array}{l}\text { Antes de examinar en qué forma los } \\
\text { Legisladores logran el objeto, y efecto del } \\
\text { comercio, expondré nueve principios, que } \\
\text { los Ingleses, Nación la mas inteligente en la } \\
\text { ciencia del comercio proponen } \\
\text { en sus libros, para juzgar si las operaciones } \\
\text { del comercio son ventajosas o no. } \\
\text { 1) La exportación, ó extracción del sobrante } \\
\text { es la ganancia mas clara, que puede hacer } \\
\text { una Nación. }\end{array}$ \\
\hline
\end{tabular}

número 39, De la navegación: 304

De la navegación: 248

Hemos visto hasta ahora a la agricultura alimentar y ocupar a los hombres; el trabajo industrioso, multiplicar sus comodidades, dando las formas a las producciones naturales, e introducir en un cuerpo político un doble aumento de medios de ocupar a sus miembros, de modo que estas dos artes están en una dependencia recíproca, cuya ligazón no puede romperse sin perjudicar a la perfección del uno y del otro; y desde luego sin frustrar a la sociedad una gran parte de su utilidad. Hemos observado que esta perfección no puede existir sin el socorro del mayor consumo exterior posible.

Hasta aquí hemos vino la Agricultura mantener y ocupar a los hombres: $Y$ al trabajo industrioso, multiplicar sus comodidades mediante las formas, que ha añadido a las producciones naturales, e introducir en un cuerpo político un doble aumento de medios para ocupar sos miembros; de modo, que tilos dos Artes se hallan en una dependencia recíproca, cuyos eslabones no pueden romperla sin hacer daño y la perfección de uno, y otro, y por consiguiente sin privar la sociedad de una gran parte de su utilidad. Ademas hemos observado, que no puede existir esta perfección sin el socorro del mayor consumo exterior posible.

número 41, 8 de diciembre de 1810: 320-321

Si la proporción es siempre exacta entre la marina de dos estados, la superioridad de la una sobre la otra dependerá de la celeridad y del secreto de los armamentos; del genio de los jefes, de la experiencia, del valor, de la impetuosidad de la gente de mar, tanto oficiales como marineros; de la manera de combatir, de la mejor combinación de las diversas expediciones recíprocas.

\begin{abstract}
Si la proporción es siempre exacta entre la Marina de dos Naciones, la superioridad de la una sobre la otra, dependerá de la prontitud , y secreto de los armamentos, del talento de los Jefes, de la experiencia, del valor, y de la fuerza de los Oficiales de Marina, como también de los Marineros, del modo de pelear, del mejor acierto de los empleados, de las escuadras, de los Arsenales, y de la mejor combinación de las varias expediciones recíprocas.
\end{abstract}

10. Eugenio del Portillo, abogado cordobés que firmaba sus colaboraciones en el Telégrafo Mercantil con el seudónimo anagramático Ennio Tullio Grope hizo referencia en "Utilidad de los periódicos", (TM, 4/10/1801) a la lectura del periódico Pensador de Clavijo y Fajardo.
La elección de los editores del Correo de Comercio no fue ajena a la que realizaron tanto José Clavijo y Fajardo como Francisco Mariano Nipho; que también tradujeron fragmentos de la obra de Verón Duverger de Forbonnais en la península décadas antes. En 1763 Clavijo y Fajardo tradujo para su periódico El pensador un fragmento del capítulo primero de la obra de Forbonnais que abordaba la historia del comercio $^{10}$. Una semana después en El habladorjuicioso y crítico imparcial de Francisco Nipho se tradujo el mismo fragmento del primer capítulo de Elémens du commerce. Clavijo volvió sobre este tema al recordar en el Pensamiento XL de su periódico que la traducción de su contrincante "dista en muchas cosas del verdadero sentido del original" para generar la reacción de Nipho que se defendió frente a tal acusación (Carpi, 2014). La investigación de Elena Carpi (2014) sostuvo que la razón por la que el ingeniero Carlos Lemaur optó por la traducción de Forbonnais fue porque le atribuyó una vital importancia a la construcción de caminos e infraestructura para mejorar la comunicación entre los mercados, las ciudades y los poblados alejados de los centros urbanos. Esa misma preocupación se encontró en el Telégrafo Mercantil que transcribió un artículo de Hipólito Unanúe "Discurso histórico sobre el nuevo 
camino del Callao de Lima" (8/11/1801) y el Semanario de Vieytes con la cita a Montesquieu en favor del comercio, y por ende de los caminos, para el fomento de las costumbres suaves. Es decir, la reproducción de la obra de Forbonnais guardaba en sí el fervor de la ilustración criolla del comercio como dulcificador de las pasiones y corrección de las costumbres gracias a la comunicación y diálogo entre los pueblos (Maggio-Ramírez, 2019).

En la versión porteña se le sumó la intervención de los editores en una nota a pie de página en el número 37 cuando el tema que se trataba estaba ligado a los trapos para la realización del papel:

No debemos pasar en silencio la recomendación que lograría entre nosotros este precioso ramo de industria acaso habrá pocos países en que pudiera establecerse con mayor economía una fábrica de papel: no ha faltado quien pensara ponerla en Chile; pero yo digo que la misma proporción ofrece cualquier punto de nuestras campañas inmediatas. Es esta una necesidad, que estamos muy cerca de experimentarla. El papel escasea, y a punto que tendremos que dejar de escribir, sino podemos aguantar un sacrificio asombroso. Hablaremos después acerca de su establecimiento, y general utilidad. (Correo de Comercio, 1970 [1810]: 281)

Si bien no se retomó la cuestión del papel, se dejó una huella territorial que marcaba una apropiación de un texto que le era ajeno ${ }^{11}$. La utilización del ejemplo como caso para anclar un problema y dilucidarlo fue una estrategia que también había utilizado Carlos Lemaur para sus lectores españoles. Tanto el traductor como los copistas porteños utilizaron problemas locales en las notas al pie para sujetar un texto a las preocupaciones de los lectores. Los textos de Verón Duverger de Forbonnais, se le atribuyeron a Belgrano por más de doscientos años tal vez por su rol como secretario del Consulado.

\section{La prensa extranjera}

Los eruditos americanos que trocaron su rol de lectores a editores de papeles periódicos tenían un apetito voraz de impresos de diferentes orígenes. Tanto en Lima como en Buenos Aires tenían las mismas preocupaciones. En el Correo de Comercio, en su número 24 del 11 de agosto de 1810 se publicó el artículo "La libertad de prensa es la principal base e la ilustración pública", seguido de "Nota" en donde se aclaraba que había sido tomado del periódico Minerva Peruana del 10 de mayo de 1810. A solo tres meses de su publicación limeña el alegato a favor de la libertad de prensa era dado a conocer entre los suscriptores porteños del Correo de Comercio. Cabe aclarar que en la antigua sede virreinal reprodujeron el mismo texto desde el periódico español El voto de la nación española, número 1 del 13 de diciembre de 1809 entre las páginas 7 y 12. Por lo que cuando se leyó el texto en clave porteña y americana habría que ponerlo en sintonía con la guerra independentista española y cómo a pesar de ese contexto todavía interpelaba a los lectores americanos. A pesar que la misma fuente impresa indicaba que era una mera transcripción, se le atribuyó el artículo sobre la libertad de prensa a Belgrano y se le cuestionó a J. A. Bossio sostener que fuera escrito por Mariano Moreno (Díaz, 2012: 273).

Vieytes fue un asiduo lector del Semanario de Agricultura y Artes dirigidos a los párrocos (1797-1808), al punto que no sólo fue su principal inspiración periodística sino que reprodujo varios textos para su propio emprendimiento periodístico. En su biblioteca se encontraron 14 tomos encuadernados en rústica con falla del tomo séptimo (Torre Revello, 1956). El periódico estaba dirigido a los párrocos
11. El problema de la producción del papel en el Río de la Plata fue tratado por Juan Luis Aguirre en su artículo "La idea liberal económica sobre el fomento de la Biblioteca en esta capital" en los números 7, 8, 9 y 10 de El grito del sud en 1812 (Urquiza Almandoz, 1972; Parada, 2009). Tanto en el Semanario de Agricultura como en el Correo de Comercio se indicaban los arribos de las embarcaciones que traían papel importado para su comercialización en el Río de la Plata. La falta de papel y su alto valor fue una constante en la prensa del siglo XIX, al punto que se publicaban avisos de pulperos que compraban libros viejos para arrancarles las hojas para hacer cartuchos para envolver la mercadería (Parada, 1998). 
como mediadores de lectura al constatar que "en España, los que labran, no leen, y los que leen, no labran" (Larriba y Dufour, 1997: 9). Vieytes también apeló al párroco ilustrado así como al ciudadano patriota para que difunda los saberes ilustrados de la sabia Europa a los labradores. Estos repetían sus quehaceres con prácticas antiguas, que no se correspondían con los tiempos ilustrados. El periódico español, al mando de Juan Antonio Melón y Francisco Antonio Zea, fue una fructífera cantera de textos para el Correo de Comercio. Por ejemplo, el 31 de marzo se comenzó a publicar en Buenos Aires el artículo "Sobre los males que causa la imaginación" pero no se indicó que había sido tomado del Semanario ibérico. En él se anoticiaba a sus lectores que reproducían un extracto escrito por Bosquillón, regente de la Facultad de Medicina de París. En los números 5 y 6 del Correo se publicó el artículo previa introducción de tres párrafos antes de transcribir por entero el texto que el Semanario español, que se publicó en Madrid el 10 de febrero de 1803 y que se compiló en el tomo XIII.

\begin{tabular}{|c|c|}
\hline $\begin{array}{l}\text { Correo de Comercio, número 5, } 31 \text { de marzo de } \\
\text { 1810: } 34-37 \text {. }\end{array}$ & $\begin{array}{l}\text { Semanario de Agricultura, } 10 \text { de febrero de } \\
\text { 1803: } 83-89\end{array}$ \\
\hline $\begin{array}{l}\text { La robustez, la salud, y el valor de que } \\
\text { gozamos (habla el autor) según vamos } \\
\text { creciendo en edad pende de nuestra primera } \\
\text { educación; y asi es que los errores que nos } \\
\text { inspiran en la infancia nos ocasionan grandes } \\
\text { perjuicios, como se advierte en los que } \\
\text { han sido educados por personas tímidas y } \\
\text { pusilánimes, que con dificultad escapan de } \\
\text { las enfermedades que les han pintado como } \\
\text { muy terribles, pues con el menor motivo se } \\
\text { exalta su imaginación y perecen. La peste, y } \\
\text { en particular las enfermedades convulsivas, } \\
\text { ofrecen frecuentes exemplos de este genero; } \\
\text { nadie está en mayor riesgo que los tímidos } \\
\text { que las presencian, ó que oyen hablar de } \\
\text { ellas; ni hay funesto efecto que no pueda } \\
\text { producir el terror. }\end{array}$ & $\begin{array}{l}\text { La robustez, la salud y el valor de que } \\
\text { gozamos según, vamos creciendo en edad } \\
\text { pende de nuestra primera educación; y asi es } \\
\text { que los errores que nos inspiran en la infancia } \\
\text { nos ocasionan grandes perjuicios, como se } \\
\text { advierte en los que han sido educados por } \\
\text { personas tímidas y pusilánimes, que con } \\
\text { dificultad escapan de las enfermedades que } \\
\text { les han pintado como muy terribles, pues con } \\
\text { el menor motivo se exalta su imaginacion } \\
\text { y perecen. La peste, y en particular las } \\
\text { enfermedades convulsivas, ofrecen frecuentes } \\
\text { exemplos de este género y nadie está } \\
\text { en mayor riesgo que los tímidos que las } \\
\text { presencian, ó que oyen hablar de ellas; ni } \\
\text { hay funesto efecto que no pueda producir el } \\
\text { terror. }\end{array}$ \\
\hline $\begin{array}{l}\text { Una larga experiencia me ha convencido } \\
\text { de que no puede tener otro origen la } \\
\text { hydrophobia, esto es, el horror al agua, que } \\
\text { se sigue á la mordedura de un animal que } \\
\text { se reputa rabioso. Para convencerse de } \\
\text { esto basta atender á la naturaleza de los } \\
\text { síntomas de la enfermedad, al modo con } \\
\text { que se manifiestan, y á los medios mejores } \\
\text { de precaverlos. Hay personas que solo al } \\
\text { ver un perro encolerizado y desconocido se } \\
\text { desmayan y experimentan convulsiones y } \\
\text { otros efectos que no se pueden atribuir sino } \\
\text { á las ideas que han recibido en la infancia de } \\
\text { la hydrophobia ó rabia; las quales juntándose } \\
\text { en su imaginación se creen perdidos sin } \\
\text { remedio, particularmente si el animal se } \\
\text { acerca á ellos, si les toca, ó moja con la } \\
\text { espuma que hecha por la boca. }\end{array}$ & $\begin{array}{l}\text { Una larga experiencia me ha convencido } \\
\text { de que no puede tener otro origen la } \\
\text { hydrophobia, esto es, el horror al agua, } \\
\text { que se sigue á la mordedura de un animal } \\
\text { que se reputa rabioso. Para convencerse } \\
\text { de esto basta atender á la naturaleza de los } \\
\text { sintomas de la enfermedad, al modo con } \\
\text { que se manifiestan, yá los medios mejores } \\
\text { de precaverlos. Hay personas que solo al } \\
\text { ver un perro encolerizado y desconocido se } \\
\text { desmayan y experimentan convulsiones y } \\
\text { otros efectos que no se pueden atribuir sino } \\
\text { á las ideas que han recibido en la infancia de } \\
\text { la hydrophobia ó rabia; las quales juntándose } \\
\text { en su imaginación se creen perdidos sin } \\
\text { remedio, particularmente si el animal se } \\
\text { acerca a ellos, si les toca, ó moja con la } \\
\text { espuma, que echa por la boca. }\end{array}$ \\
\hline
\end{tabular}


Correo de Comercio, número 6, 7 de abril de 1810: 41-45.

Nadie ignora que es común á todos los perros enfermos el reusar los alimentos, estar tristes, tener la vista esquiva, y despreciar los alhagos de su amo: y que les sale espuma de las fauces y de las narices en las inflamaciones de la garganta y de los pulmones, principalmente en una especie de esquinancia contagiosa entre estos animales. El célebre Dufouillou admite siete especies de rabia: nos dice que son incurables y que se contagian entre los perros como la peste entre los hombres; pero cree que las demás no se contagian.

El furor de un perro no indica el virus; pues siendo un animal por su naturaleza ardiente y feroz, fácilmente se pone furioso quando se obstinan en irritarle y perseguirle, y mas si se vé herido, que se tira á los que le amenazan, y quanto se le opone aumenta entonces su ferocidad.
Nadie ignora que es común á todos los perros enfermos el reusar los alimentos, estar tristes, tener la vista esquiva, y despreciar los alhagos de su amo: y que les sale espuma de las fauces y de las narices en las inflamaciones de la garganta y de los pulmones, principalmente en una especie de esquinancia contagiosa entre estos animales. El célebre Dufouillou admite siete especies de rabia: nos dice que son incurables y que se contagian entre los perros como la peste entre los hombres; pero cree que las demás no se contagian.

El furor de un perro no indica el virus; pues siendo un animal por su naturaleza ardiente y feroz, fácilmente se pone furioso quando se obstinan en irritarle y perseguirle, y mas si se vé herido, que se tira á los que le amenazan, y quanto se le opone aumenta entonces su ferocidad.

El tomo XIII del Semanario ibérico recopiló los números del primer semestre de 1803 y fue utilizado por Vieytes en la transcripción de distintos artículos en su publicación porteña en 1804. Los periódicos contaban con foliación corrida para que luego puedan ser encuadernados por los lectores y suscriptores. Los remanentes se vendían encuadernados como libros que llegaron a Buenos Aires. Un ejemplo de la influencia del periódico de Melón y Zea en Buenos Aires se halló en el Semanario de Vieytes del 4 de abril de 1804 donde los artículos "De la imaginación considerada como causa y remedio ..." y "Juguetes perjudiciales a la salud de los niños" provenían del tomo XIII del Semanario ibérico de 1803 . Por ejemplo el texto sobre la imaginación se publicó el 3 de marzo de 1803 y el artículo sobre los juguetes el 6 de enero de 1803 en Madrid. Tanto en la biblioteca de Vieytes como en los libros donados por Manuel Belgrano en 1811 a la Biblioteca Pública de Buenos Aires se encontraban los tomos del Semanario de Agricultura e Industria dirigido a los párrocos. Temas como la relación entre la imaginación y la salud, que fue abordado en 1803 del Semanario ibérico en su tomo XIII se reprodujo en Buenos Aires en 1804 y continuó el abordaje del tema en 1810. Los editores del Correo de Comercio tomaron la precaución de evitar repetir artículos del Semanario ibérico que ya habían sido reproducidos en el periódico de Vieytes. Por lo que una vez más se pone en duda a Belgrano como único editor del Correo de Comercio y se fortalece la hipótesis del trabajo compartido.

\section{El traductor oculto}

Los editores para darle un mayor abolengo a su publicación y evidenciar que recibían noticias de distintos rincones de Europa, eliminaron la mención de los periódicos españoles o americanos. Solían atribuir el texto al periódico original, principalmente francés, pero no así a la traducción española que seguían punto por punto. En el número 18 del Correo de Comercio el artículo "Agricultura. Del modo de conseguir buena fruta, temprana y de tener algunos árboles con prontitud" se transcribe con una nota a pie de página que informa ser tomado de Elementos de agricultura pero deja de lado que en rigor es la transcripción del Semanario de Agricultura y Artes de 1804 que retomó los Elementos de Fillipo Re y los publicó el 16 de agosto de 1804. En el número 19 del Correo de Comercio, el artículo "Del mejor modo de preparar el extracto gómoso de ópio" declara haber sido tomado de los Anales de química, cuando en realidad pertenece al Semanario de Agricultura y Artes, número 412, 22 de noviembre de 1804 
que lo tradujeron de la publicación francesa Annales de chimie, tomo 46, escrito por Leroux. En el número 20 sucedió lo mismo con "Remedio para la gota" que en nota al pie se declaraba transcripción de "Carta del médico Tronchin, extracto" cuando fue tomada otra vez del mismo tomo del Semanario de Agricultura, número 402 del 13 de septiembre de 1804 . De la misma fecha es el artículo que bajo el título "Remedio para la hidropesia" declaraba ser tomado de una Gazeta de Bayona cuando en realidad fue transcripto del Semanario de Agricultura y Artes, número 402, de la misma fecha.

\section{El lector como autor}

El artículo que bajo el título "Industria" se publicó el 21 de abril de 1810 en el Correo de Comercio tiene una particularidad que fue pasada por alto en las distintas antologías en las que fue recopilado y atribuido a Manuel Belgrano. Al finalizar el texto puede leerse en tipografía cursiva la palabra "Remitido", que podría implicar por un lado que fue una estrategia de los editores para deslindar responsabilidades de su escrito y por otro lado podría indicarse que el artículo tal vez fue enviado por un lector y reproducido en el Correo. Ese gesto se confirma un par de páginas más adelante cuando en el número 14 de la publicación se inserta una carta firmada por "Un suscriptor" dirigida a los "Señores editores" para cuestionar algunos puntos de aquella intervención. Los lectores contemporáneos sabían que frente al anonimato del texto la palabra "Remitido" eximía de responsabilidad autoral al editor del periódico frente a las autoridades virreinales.

Incorporar la carta firmada por un suscriptor, ficticio o real, que discutiera con el texto remitido era una manera de establecer un diálogo para fortalecer la comunidad de lectores en torno al periódico. Vieytes supo intervenir en su periódico con las cartas ficcionales que supuestamente le dirigía un hermano suyo en la campaña bonaerense, por lo que incluía detalles para sostener la verosimilitud de la epístola (Maggio-Ramírez, 2008).

\section{Conclusiones}

La prensa porteña virreinal fue el instrumento para la difusión del conocimiento, de las doctrinas ligadas a la economía política pero principalmente se encargó de la crítica de costumbres. Los inventarios bibliográficos en los testamentos, las menciones de libros en la prensa tardocolonial dieron cuenta de la amplia circulación de la literatura ficcional y ensayística en el Río de la Plata. También dejaron su huella en las obras que fueron "apropiadas" por los editores, aunque en la mayoría de los casos hallados en el Correo de Comercio no se declaró el origen de los textos.

El "Prospecto" del Correo de Comercio, escrito por Manuel Belgrano, dejó en claro que Buenos Aires era ya digna de ser tratada como un par por las ciudades europeas. La literatura didáctica, que años antes había tomado las páginas en el Semanario de Vieytes con instrucciones desde cómo preparar tinta china hasta la forma de realizar manteca, no fue el género literario predominante en el Correo de Comercio. Su espacio había sido ganado por la economía política como un arte discreto que permitía enunciar políticas de gobierno en tiempos revolucionarios. Las élites letradas, desde Nueva Granada hasta Buenos Aires, adoptaron el dogma de la economía política como sinónimo de felicidad colectiva e individual. Se sostuvo que el "lucro, el interés y la ganancia son los motivos básicos del obrar humano" en búsqueda de la prosperidad material que fomentaría una "vida social más amable, [...] una vida social menos sometida al peso de la mínima satisfacción y, en cambio, rodeada de un cierto nivel de riqueza que se convirtiera en un principio de civilización" (Silva, 2005: 28). De 
alguna manera ya lo había enunciado Montesquieu y citado Vieytes en su periódico:

"El comercio cura las preocupaciones destructivas".

Belgrano, sin pudor, escribió en el Prospecto que "[... Buenos Aires es] la gran Capital de la América Meridional, [es] digna hoy de todas las atenciones del mundo civilizado". Ese mundo es el europeo, desde donde emanan las luces de la Ilustración, que oficiaba como meta de llegada. Era norma y espejo donde mirarse. Buenos Aires, era digna "hoy" -escribió Belgrano- a unos meses de la Revolución de Mayo, de las atenciones de Europa por lo que tenía que estar a la par. La prensa porteña tenía que fomentar las mismas discusiones que tenían las tertulias ilustradas europeas. La puesta en escena de la circulación de la cultura impresa buscó eliminar las intermediaciones para que Buenos Aires estuviera en la misma mesa que las ciudades europeas.

El problema de la autoría fue arrumbado en el cajón decimonónico de la biografía positivista, vinculado a la figura del genio creador solitario pero se buscó instalarlo "como noción histórica y cultural susceptible de estudio en sí misma (Donald Pease, 1990; Steven Bernas, 2001), que aspira a la compresión del complejo proceso en que se constituye la propia figura del autor [...]" (Lorenzo Álvarez, 2017: IX) La autoría dejó de estar asociada al corpus legislativo para pensarse en relación con las condiciones materiales de producción, los canales de circulación y las distintas instancias de apropiación del texto. La autoría en el periódico colonial, donde se utilizaban seudónimos anagramáticos entre tantas máscaras autorales, queda aún por analizar en sus distintas aristas pero se puede conjeturar que al menos cuando se trataba de visibilizar la producción europea la élite letrada no se preocupó en la figura del autor, sino en la intervención del texto en la comunidad local. La prensa operó como intermediaria de las lecturas que sus editores habían realizado en libros y periódicos. La difusión de los textos instruccionales, de las críticas de costumbres y criterios de economía política forjaron lectores con una identidad de múltiple adscripción. Por ejemplo, Manuel José de Lavardén publicó encendidas críticas como americano español frente a la obra de Cornelius de Paw, que llegó a reproducirse no sólo en el Semanario de Vieytes sino también en el Regañón General madrileño.

Tal vez se deba buscar un sutil equilibrio entre aquellos estudios que alimentaron la figura de Belgrano como un erudito polígrafo, que escribía con soltura sobre cualquier tema a su alcance, y Belgrano como un erudito a la violeta, al decir de José Cadalso (1772) que buscaba aparentar saberes que le eran ajenos, como escribió Tulio Halperin Donghi cuando recordó que el prócer de la bandera propuso

dotar a cada vivienda de un horno de Rumford [por lo que] no sólo confunde dos de las más célebres invenciones de este conde del Sacro Imperio nacido en Massachusetts, a saber, el horno que disminuía drásticamente el volumen de leña requerido en la producción de cal viva utilizada por Cerviño y Vieytes, y la chimenea cuyo diseño -utilizado hasta hoy- no sólo aprovechó mejor el calor creado por la combustión de la leña sino liberó a quienes daba abrigo de sufrir las consecuencias del deficiente tiraje. Más grave es que no entrase siquiera a considerar todo lo que había inviable el proyecto [...] (Halperin Donghi, 2014: 80).

Probablemente, tanto Belgrano como Vieytes cumplieron el rol que ya había propuesto Cabello y Mesa, al oficiar como lectores voraces que quisieron contagiar su entusiasmo a los suscriptores de los periódicos. Es decir, antes que nada Belgrano fue un ávido lector.

La circulación de la información, entre la publicación original y su reproducción porteña, no se redujo a menos de los tres meses. Las fuentes impresas españolas 
y su reescritura, podría interpretarse como una acción que privilegiaba la difusión de las ideas en favor del bien público. Los textos atribuidos a Belgrano en distintas antologías que se replicaron desde 1956 ameritan una revisión, gracias al proceso de digitalización de la información y su libre acceso en repositorio públicos internacionales. Luego de la comparación realizada sostener la atribución autoral es desconocer la circulación de la cultura impresa y de las apropiaciones que de ella se hizo a principios del siglo XIX. La corrección de la autoría permitiría, principalmente, reponer la circulación de los saberes entre la comunidad letrada colonial y reivindicar a Belgrano como lector omnívoro. 


\section{Q Referencias bibliográficas}

»Arata, Nicolás. 2011. La formación del artesano en los escritos de Manuel Belgrano. En Revista del IICE. No.3, 57-72. <http://revistascientificas.filo.uba.ar/index.php/iice/article/view/145/107> [Consulta: 22 febrero 2020].

" Astigarraga, Jesús y Juan Zabalza. 2009. "Economía Política” y “Comercio" en los diccionarios y la literatura enciclopédica española del siglo XVIII. En BuIletin hispanique. No. 111-2, 387-427. <https://doi.org/10.400o/bulletinhispanique.998>

»Aullón de Haro, Pedro. 1987. Los géneros didácticos y ensayísticos en el siglo XVIII. Madrid: Taurus.

"Barral, María Elena. 2007. Disciplina y civilidad en el mundo rural de Buenos Aires a fines de la Colonia. En Jahrbuch für Geschichte Lateinamerikas = Anuario de Historia de América Latina (JbLA ). Vol. 44, no. 1, 135-55. <https://doi.org/10.7767/ jbla.2007.44.1.135>

"Beltrán, Oscar R. 1943. Historia del periodismo argentino, pensamiento y obra de los forjadores de la patria. Buenos Aires: Sopena. <http://anaforas.fic.edu.uy/ jspui/handle/123456789/32715> [Consulta: 22 febrero 2020].

»Caillet-Bois, Julio. 1958. La literatura colonial. En Arrieta, Rafael Alberto. Historia de la literatura argentina. Buenos Aires: Peuser. Vol. 1, p. 5-259.

»Caillet-Bois, Ricardo Rodolfo. 1929. Ensayo sobre el Río de la Plata y la Revolución Francesa. Buenos Aires: Facultad de Filosofía y Letras, Instituto de Investigaciones Históricas.

»Carpi, Elena. 2014. The Spanish Translation of the Elémens du Commerce by François Véron Duverger de Forbonnais: A Linguistic Analysis. En History of European Ideas. Vol. 40, no. 8, 1108-1129. <https://doi.or g/10.1080/01916599.2014.968335>

"Casanello, Oreste Carlos. 2008. Ciudadano/Vecino. En Goldman, Noemí, ed. Lenguaje y revolución : conceptos políticos clave en el Río de la Plata, 1780-1850. Buenos Aires: Prometeo Libros. p. 19-34.

"Catálogo de la donación del General Manuel Belgrano. Con la nómina de las obras extraviadas y un índice de materias. 1936. Buenos Aires: Biblioteca Nacional.

»Catálogo del periodismo e imprenta argentina: inauguración del salón exposición en el Museo Histórico Nacional, 7 de junio de 1960. 1960. Buenos Aires: Ministerio de Educación y Justicia, Dirección General de Cultura, Museo Histórico Nacional.

»Chartier, Roger. 1994. ¿Qué es un autor? En Chartier, Roger. Libros, lecturas y lectores en la Edad Moderna. Madrid: Alianza. p. 58-89.

"Chartier, Roger. 2006a. Epílogo. Diderot y sus corsarios. En Chartier, Roger. Inscribir y borrar. Cultura escrita y literatura (siglos XI-XVIII). Buenos Aires: Katz. p. 215-238.

»Chartier, Roger. 2006b. ¿Qué es un libro? En Chartier, Roger, ed. ¿Qué es un texto? Madrid: Círculo de Bellas Artes. p. 9-35.

»Chartier, Roger. 2016. La mano del autor y el espíritu del impresor: siglos XVI-XVIII. Buenos Aires: Katz - Eudeba. 
"Chiaramonte, José Carlos. 2007. La llustración en el Río de la Plata. Cultura eclesiástica y cultura laica durante el Virreinato. Buenos Aires: Sudamericana.

»Deacon, Philip. 2014. Máscaras culturales. Tácticas y juegos autoriales en la España dieciochesca. En Maud Le Guellec, ed. El autor oculto en la literatura española. Siglos XIV a XVIII. Madrid: Casa de Velázquez. p. 107-122.

» Díaz, César L. 2012. Comunicación y revolución, 1759-1810: esfera y espacio público rioplatense: periodismo, censura, prácticas y ámbitos de lectura. La Plata: Facultad de Periodismo y Comunicación Social, Universidad Nacional de La Plata, Ediciones de Periodismo y Comunicación.

»Dib, Matías. 2016. Introducción. En Manuel Belgrano y la economía política: compilación documental. Buenos Aires: Instituto Nacional Belgraniano; EDICON, Fondo Editorial Consejo, Consejo Profesional de Ciencias Económicas de la Ciudad Autónoma de Buenos Aires. p. 17-34.

»Echagüe, Juan Pablo. 1938. El periodismo. En Historia de la Nación Argentina. El momento histórico del Virreinato del Río de la Plata, editado por Ricardo Levene. Vol. IV. Buenos Aires: Academia Nacional de la Historia. p. 79-94.

»Fernández Armesto, María Verónica. 2005. Lectores y lecturas económicas en Buenos Aires a fines de la época colonial. En Información, Cultura y Sociedad. No. 13, 29-56. <http://revistascientificas.filo.uba.ar/index.php/ICS/article/ view/897> [Consulta: 22 febrero 2020].

» Fernández, Juan Rómulo. 1943. Historia del periodismo argentino. Buenos Aires: Librería Perlado Editores.

»Fernández López, Manuel. 1976. Comprobaciones, refutaciones y problemas no resueltos del primer pensamiento económico argentino. Buenos Aires: Instituto de Investigaciones Económicas de la Universidad de Buenos Aires. <http:// aaep.org.ar/anales/works/works1976/FernandezLopez.pdf> [Consulta: 22 febrero 2020].

» Fernández López, Manuel. 2005. Cartas de Foronda: su influencia en el pensamiento económico argentino. En 40ํReunión Anual de la Asociación Argentina de Economía Política. La Plata. <https://aaep.org.ar/anales/works/works2005/ fernandezlopez.pdf> [Consulta: 22 febrero 2020].

»Finkelstein, David y Alistair McCleery. 2014. Autores, autoría, autoridad. En Finkelstein, David y Alistair McCleery. Una introducción a la historia del libro. Buenos Aires: Paidós. p. 127-158.

» Fitte, Ernesto J. 1970. Introducción. En Correo de Comercio. Buenos Aires: Academia Nacional de la Historia. p. 9-20.

» Furlong, Guillermo. 1944. Bibliotecas argentinas durante la dominación hispánica. Buenos Aires: Huarpes.

"Furlong, Guillermo. 1969. Historia social y cultural del Río de la Plata: 1536-1810 : el transplante cultural, arte. Buenos Aires: Tea.

»Gagliano, Rafael S. 2011. Presentación. Manuel Belgrano: Dilemas del pensamiento educativo de un ilustrado católico y revolucionario. En Belgrano, Manuel. Escritos sobre educación: selección de textos. La Plata: UNIPE Editorial Universitaria. p. 9-29. <http://biblioteca.clacso.edu.ar/Argentina/unipe/20171121062036/pdf_347.pdf> [Consulta: 22 febrero 2020].

" Galván Moreno, Carlos. 1944. El periodismo argentino. Amplia y documentada historia desde sus orígenes hasta el presente. Buenos Aires: Claridad. <http://anaforas.fic.edu.uy/jspui/handle/123456789/32716> [Consulta: 22 febrero 2020]. 
» Goldgel, Víctor. 2013. Cuando lo nuevo conquistó América: prensa, moda y literatura en el siglo XIX. Buenos Aires: Siglo Veintiuno Editores.

»Gómez de Mier, Eugenio. 2003. Presentación. En Correo de comercio: 3 de marzo de 1810 a 25 de agosto de 1810. Buenos Aires: Editorial Docencia. p. 5-8.

" Gutiérrez, Juan María. 1866. Bibliografía de la primera imprenta de Buenos Aires desde su fundación hasta el año de 1810 inclusive: ó Catálogo de las producciones de la Imprenta de Niños espósitos, con observaciones y noticias curiosas, precedida de una biografía del virey Don Juan José de Vértiz y de una disertación sobre el orijen del arte de imprimir en América y especialmente en el Rio de la Plata. Mayo. Buenos Aires: Imprenta de Mayo. <https://books.google.com.ar/books?id=Fb EtAAAAYAA]\&hl=es\&pg=PA1\#v=onepage\&q\&f=false $>$ [Consulta: 26 octubre 2019].

» Halperin Donghi, Tulio. 2014. El enigma Belgrano: un héroe para nuestro tiempo. Buenos Aires: Siglo Veintiuno Editores.

" Larriba, Elisabel. 2013. El público de la prensa en España a finales del siglo XVIII (1781-1808). Zaragoza: Prensas de la Universidad de Zaragoza.

"Larriba, Elisabel y Gérard Dufour. 1997. El Semanario de agricultura y artes dirigido a los párrocos 1797-1808. Valladolid: Ámbito.

"Lorenzo Álvarez, Elena de. 2017. Introducción. En Lorenzo Álvarez, Elena de, ed. Ser autor en la España del siglo XVIII. Gijón: Trea. p. IX-XIV.

" Maggio-Ramírez, Matías. 2008. Un puro vegetar. Representaciones de la lectura en el Semanario de Agricultura, Industria y Comercio. (1802-1806). En Brunetti, Paulina, Matías Maggio-Ramírez y María del Carmen Grillo. Ensayos sobre la prensa: Primer Concurso de Investigación en Periódicos Argentinos en Homenaje al Prof. Jorge B. Rivera. Ciudad Autónoma de Buenos Aires: Biblioteca Nacional. p. $205-292$.

»Maggio-Ramírez, Matías. 2011. Configuraciones de la lectura en el Buenos Aires virreinal a través de sus periódicos. En Bestani, Rosa M., et al, eds. Textos, autores y bibliotecas: 190 años de la Biblioteca Mayor de la UNC. Córdoba: Universidad Nacional de Córdoba. p. 359-368.

» Maggio-Ramírez, Matías. 2015. El color de la palabra. Sobre la sátira de Manuel José de Lavardén y su polémica en el Telégrafo Mercantil (1786-1801). En Dieciocho: Hispanic enlightenment. Vol. 38, no. 2, 219-238. <https://www.aacademica. org/maggioramirez/7> [Consulta: 22 febrero 2020].

» Maggio-Ramírez, Matías. 2017. El Telégrafo Mercantil y el fomento de la civilidad. El nacimiento de la prensa de costumbres en el Buenos Aires virreinal. En Historia y Comunicación Social. Vol. 22, no. 1, 31-44. <https://doi.org/10.5209/ HICS. $55898>$

" Maggio-Ramírez, Matías. 2019. El comercio como signo de civilidad en la prensa colonial de Buenos Aires (1801-1810). En Res Publica. Revista de Historia de las Ideas Políticas. Vol. 22, no. 1, 87-104. <https://doi.org/10.5209/RPUB.63886>

" Martínez de Sousa, José. 2004. Diccionario de bibliología y ciencias afines: terminología relativa a archivística, artes e industrias gráficas, bibliofilia, bibliografía, bibliología, bibliotecología, biblioteconomía. 3. ed. Gijón, Asturias: Trea.

» Martínez Gramuglia, Pablo F. 2009. El pensamiento agrario ilustrado en el Río de la Plata: un estudio del Semanario de Agricultura, Industria y Comercio (1802-1807). En Mundo agrario. Vol. 9, no. 18. <http://sedici.unlp.edu.ar/handle/10915/13326> [Consulta: 22 febrero 2020]. 
»Martínez Gramuglia, Pablo F. 2010. A la búsqueda de lectores: El Telégrafo Mercantil. En Question. Vol. 1, no. 27. <http://perio.unlp.edu.ar/ojs/index.php/ question/article/view/1000> [Consulta: 22 febrero 2020].

»Martini, Mónica Patricia. 1998. Francisco Antonio Cabello y Mesa: un publicista ilustrado de dos mundos (1786-1824). Buenos Aires: Instituto de Investigaciones sobre Identidad Cultural, Universidad del Salvador.

» Martini, Mónica Patricia. 1999. La imprenta y el periodismo. En Nueva historia de la Nación Argentina. Período español (1600-1810). Buenos Aires: Planeta. Tomo 3, 315-332.

»Mitre, Bartolomé. 1859. Historia de Belgrano. Buenos Aires: Libreria de la Victoria.

"Navallo, Tatiana. 2010. Ideas ilustradas: de los manuscritos al Proyecto Geográfico en el Telégrafo Mercantil (1801-1802). En Tinkuy: Boletín de investigación y debate. No. 14, 159-197. <https://lm.umontreal.ca/fileadmin/Documents/ FAS/litterature_langue_monde/Documents/2-Recherche/Tinkuyn.14_oo1.pdfs [Consulta: 22 febrero 2020].

"Navallo, Tatiana. 2011. La introducción a la Historia Natural de Tadeo Haenke y las representaciones de la naturaleza en la conformación del Alto Perú. En Antíteses. Vol. 4, no. 8, 703-728. <http://www.uel.br/revistas/uel/index.php/antiteses/article/view/8160/9469> [Consulta: 22 febrero 2020].

»Parada, Alejandro E. 1998. El mundo del libro y de la lectura durante la época de Rivadavia: una aproximación a través de los avisos de La Gaceta mercantil (18231828). Buenos Aires: Instituto de Investigaciones Bibliotecológicas, Facultad de Filosofía y Letras, Universidad de Buenos Aires.

"Parada, Alejandro E. 2009. Los orígenes de la Biblioteca Pública de Buenos Aires : antecedentes, prácticas, gestión y pensamiento bibliotecario durante la Revolución de Mayo (1810-1826). Buenos Aires: Instituto de Investigaciones Bibliotecológicas, Facultad de Filosofía y Letras, Universidad de Buenos Aires.

»Parada, Alejandro E. 2012. El dédalo y su ovillo. Ensayos sobre la palpitante cultura impresa en la Argentina. Buenos Aires: Instituto de Investigaciones Bibliotecológicas, Facultad de Filosofía y Letras, Universidad de Buenos Aires.

»Pastore, Rodolfo y Nancy Calvo. 200o. Cultura colonial, ideas económicas y formación superior ilustrada en el Río de La Plata. El caso de Manuel Belgrano. En Prohistoria. Historia, políticas de la historia. No. 4, 27-58. <https://dialnet.unirioja.es/servlet/articulo?codigo $=5852393>$ [Consulta: 22 febrero 2020].

"Pastore, Rodolfo y Nancy Calvo. 2005. Ilustración y economía en el primer periódico impreso del Virreinato del Río de la Plata: el "Telégrafo Mercantil” (18011802). En Bulletin hispanique. Vol. 107, no. 2, 433-462. <https://www.persee.fr/ doc/hispa_0007-4640_2005_num_107_2_5237> [Consulta: 22 febrero 2020].

»Peire, Jaime. 2008. Leer la Revolución de Mayo: bibliotecas tardocoloniales en el Río de la Plata. En Eadem Utraque Europa. Año 4, no. 6, 109-155.

»Pigna, Felipe. 2016. Manuel Belgrano. El hombre del bicentenario. Buenos Aires: Planeta.

»Primeras donaciones de libros a la Biblioteca Nacional de Buenos Aires. 1944. En Revista de la Biblioteca Nacional. Vol. 10, no. 30, 493-504.

»Rivera, Ángel y Raúl Quintana. 1945. Los géneros periodísticos en la época colonial. En El Monitor de la Educación Común. Año 64, no. 86-866, 3-99. 
»Rojas, Ricardo. 1924. La literatura argentina. Ensayo filosófico sobre la evolución de la cultura en el Plata. Los coloniales. 2ª . ed. Buenos Aires: Librería "La Facultad».

»Silva, Renán. 2005. La llustración en el virreinato de Nueva Granada : estudios de historia cultural. Medellín: Carreta Editores.

" Torre Revello, José. 1940. El libro, la imprenta y el periodismo en América durante la dominación española. Buenos Aires: Facultad de Filosofía y Letras, Universidad de Buenos Aires; Talleres de Peuser.

» Torre Revello, José. 1956. La biblioteca de Hipólito Vieytes. En Historia. Año 2, no. 6, 72-89.

» Torre Revello, José. 1965. Bibliotecas en el Buenos Aires antiguo desde 1729 hasta la inauguración de la Biblioteca Publica en 1812. En Revista de Historia de América. No. 59, 1-148.

»Urquiza Almandoz, Oscar F. 1972. La cultura de Buenos Aires a través de su prensa periódica desde 1810 hasta 1820. Buenos Aires: Eudeba.

»Urzainqui, Inmaculada. 2003. Un nuevo sistema de escritura y de lectura: la prensa periódica. En Historia de la edición y de la lectura en España, 1472-1914. Madrid: Fundación Germán Sánchez Ruipérez. p. 378-89

»Urzainqui, Inmaculada. 2009. Periodista- espectador en la España de las Luces. La conciencia de un género nuevo de escritura periodística. En El Argonauta español. No. 6. <https://doi.org/10.400o/argonauta.516>

»Usoz, Javier. 2013. Los prólogos económicos y la esfera pública ilustrada en España. En Astigarraga, Jesús y Javier Usoz, eds. L'économie politique et la sphére publique dans le débat des Lumières. Madrid: Casa de Velázquez. p. 83-101.

»Wedovoy, Enrique. 1955. Estudio preliminar. En Lavardén, Manuel José de. Nuevo aspecto del comercio en el Río de la Plata. Buenos Aires: Raigal. p. 9-108.

»Weinberg, Félix. 1956. Estudio preliminar. En Vieytes, Juan Hipólito. Antecedentes económicos de la revolución de mayo. Buenos Aires: Raigal. p. 13-133.

»Weinberg, Gregorio. 1954. Introducción. En Belgrano, Manuel. Escritos económicos. Buenos Aires: Editorial Raigal. p. 7-46.

»Zinny, Antonio. 1869. Efemeridografía argirometropolitana hasta la caída del gobierno de Rosas. Buenos Aires: Imprenta del Plata.

\section{Fuentes}

»Belgrano, Manuel. 1960. Autobiografía del general Don Manuel Belgrano, que comprende desde sus primeros años (1770) hasta la Revolución del 25 de Mayo. Con notas del General Don Bartolomé Mitre. En Senado de la Nación. Biblioteca de Mayo. Autobiografías. Buenos Aires: Imprenta del Congreso de la Nación. Biblioteca de Mayo. Tomo 2, 955-968.

»Cadalso, José. 1772. Los eruditos a la violeta o curso completo de todas las ciencias para los siete días de la semana [...]. Madrid: Antonio de Sancha. <http://www. cervantesvirtual.com/obra-visor/los-eruditos-a-la-violeta--3/html/ff14bdd282b1-11df-acc7-002185ce6064_2.html> [Consulta: 22 febrero 2020].

»Correo de Comercio. 1970 [1810-1811]. Buenos Aires: Academia Nacional de la Historia. 
»Duverger de Forbonnais, Veron. 1765. Elementos del Comercio. Traducido por Carlos Le-Maur. Madrid: En casa de los Hermanos Orcel; en la Imprenta de Francisco Javier Garcia. <https://books.google.com.ar/> [Consulta: 26 octubre 2019].

»El Voto de la Nación española. 1809. Sevilla: Imprenta Real. <https://books.google.com.ar/> [Consulta: 26 octubre 2019].

"Espíritu de los mejores diarios literarios que se publican en Europa. 1789. Madrid: Imprenta Antonio Espinosa. <https://books.google.com.ar/> [Consulta: 26 octubre 2019].

"Semanario de Agricultura, Industria y Comercio. 1802-1803. 1928. Reimpresión facsimilar. Vol. 1. 5 vols. Buenos Aires: Junta de Historia y Numismática Americana.

"Semanario de Agricultura y Artes: dirigido a los párrocos. 1797. Madrid: en la imprenta de Villalpando. <http://hemerotecadigital.bne.es/index.vm> [Consulta: 22 febrero 2020].

"Smith, Adam. 1794. Investigación de la Naturaleza y Causas de la Riqueza de las Naciones. Valladolid: Oficina de la viuda e Hijos de Santander. <https://books. google.com.ar/> [Consulta: 26 octubre 2019].

"Telégrafo Mercantil: rural, político-económico e historiógrafo del Río de la Plata [1 de abril al 27 de diciembre de 1801]. 1914. Buenos Aires: Junta de Historia y Numismática Americana. 